\title{
Pelvimetry by Reformatted Computed Tomography in 290 Female Pelvis. Morphometric Variations Regarding Age
}

\author{
Pelvimetría Mediante Tomografía Computadorizada Reformada sobre 290 Pelvis \\ Femeninas. Variaciones Morfométricas de Acuerdo a la Edad
}

\begin{abstract}
Miguel Ángel Vázquez-Barragán*; Azalea Garza-Báez**; Rodolfo Morales-Avalos*; Brenda Martínez-González*; Guillermo Jacobo-Baca*; Ricardo Pinales-Razo**; Alejandro Quiroga-Garza*; David de la Fuente-Villarreal"; Guillermo Elizondo-Riojas*; Rodrigo E. Elizondo-Omaña* \& Santos Guzmán-López*
\end{abstract}

VÁZQUEZ-BARRAGÁN, M.A; GARZA-BÁEZ,A.; MORALES-AVALOS, R.; MARTÍNEZ-GONZÁLEZ, B.; JACOBO-BACA, G.; PINALES-RAZO, R.; QUIROGA-GARZA, A.; DE LA FUENTE-VILLARREAL, D.; ELIZONDO-RIOJAS, G.; ELIZONDOOMAÑA, R. E. \& GUZMÁN-LÓPEZ, S. Pelvimetry by reformatted Computed Tomography in 290 female pelvis. Morphometric variations regarding age. Int. J. Morphol., 34(1):298-304, 2016.

SUMMARY: The Mexican government passed a new reform of article 11 of the General Law in 2014 regarding Women's Access to a Life Free of Violence, which states that a cesarean section may not be performed if a vaginal birth is viable. Cesarean sections are excessively indicated in Northen Mexico, using the diagnosis of cephalopelvic disproportion due to a narrow pelvis. Currently, there is no standardized morphometry of the female pelvis in a Mexican population to establish adequate diagnostic parameter. Our study measures the pelvic diameters of the birth canal using abdominopelvic computed tomography (CT). Two hundred and ninety CT from Mexican women between the ages of 18 and 50 were collected and 3D reformatted in order to morphologically measure the pelvic diameters of clinical relevance. Measurements were conducted by two diagnostic imaging specialists. The mean and standard deviation of the measured diameters were: anatomical conjugate diameter (ACD) $11.65 \pm 0.99 \mathrm{~cm}$, the obstetric conjugate diameter (OCD) $11.73 \pm 0.98$ $\mathrm{cm}$, diagonal conjugate diameter (DCD) $12.49 \pm 0.98 \mathrm{~cm}$ and Interspinous distance (ISD) $10.41 \pm 0.78 \mathrm{~cm}$. Significant differences were found in all four mean diameters in between the 20-29 age groups versus the >40, as well as between the 30-39 groups versus the >40. Our study shows that as Mexican women get older, the mean pelvic diameters become narrower.

KEY WORDS: Pelvimetry; Cesarean; Cephalopelvic disproportion; Reformatted CT; Morphometry; Mexico.

\section{INTRODUCTION}

In the last two decades, unjustified cesarean births have increased in Northeastern Mexican middle and high income women (Puentes-Rosas et al., 2004). Approximately 18.5 million cesareans are performed annually around the world, of which half are considered unnecessary (Gutierrez et al., 2012). Correct indications for obstetric interventions are essential in order to reduce maternal and perinatal mortality (Rozenholc et al., 2007). When these are performed in unnecessary cases, besides the additional costs generated to the health system, it can cause negative effects on the health of the mother and newborn (Campero et al., 2007; Puentes-Rosas et al.). These include complications such as a higher incidence of preterm birth and neonatal death (Villar et al., 2007), increased risk of placenta previa, placenta accreta and hysterectomy in subsequent pregnancies (Cárdenas, 2002; Penn \& Ghaem-Maghami, 2001), and surgical wound infection, necrotizing fasciitis and endometritis after cesarean section (Cardenas).

The indications for a cesarean are: dystocia, previous cesarean section, fetal distress and abnormal presentations (Campero et al.; Tita, 2012). Dystocia is the most common indication for cesarean with a prevalence varying from 40 $\%$ to $50 \%$ (Lenhard et al., 2009; Tita), and is also the most common maternal problem (Alijahan et al., 2014) associated with increased maternal and fetal morbidity and mortality (Lenhard et al., 2010; Rozenholc et al.).

\footnotetext{
* Department of Human Anatomy, Faculty of Medicine and University Hospital "Dr. José Eleuterio González", Universidad Autónoma de Nuevo León, Nuevo León, México.

** Departament of Radiology and Imaging, University Hospital “Dr. José Eleuterio González”, Universidad Autónoma de Nuevo León, Nuevo León, México.
} 
VÁZQUEZ-BARRAGÁN, M. A; GARZA-BÁEZ, A.; MORALES-AVALOS, R.; MARTÍNEZ-GONZÁLEZ, B.; JACOBO-BACA, G.; PINALES-RAZO, R.; QUIROGA-GARZA, A.; DE LA FUENTE-VILLARREAL, D.; ELIZONDO-RIOJAS, G.; ELIZONDO-OMAÑA, R. E. \& GUZMÁN-LÓPEZ, S. Pelvimetry by reformatted Computed Tomography in 290 female pelvis. Morphometric variations regarding age. Int. J. Morphol., 34(I):298-304, 2016.

There are several types of dystocia, the most common is cephalopelvic disproportion (Lenhard et al., 2010). This occurs when there is a discrepancy between the fetal size and the size of the maternal pelvis (Korhonen et al., 2014). Its diagnosis is crucial in order to determine if the pregnancy should be interrupted surgically and it is carried out by a subjective clinical evaluation which estimates the size of the pelvic cavity through a digital examination of the bony pelvis (Cunningham et al., 2001). This clinical pelvimetry has been reported to have limited value in identifying women at risk of dystocia (Rozenholc et al.) and is prone to subjectivity (Tita), reason why a more objective and reliable method is needed (Lenhard et al., 2009, 2010).

Different imaging studies have been used for pelvimetry to identify the small pelvic diameters, examples include: ultrasound (Daghighi et al., 2013), X rays (Harper et al., 2013; Korhonen et al., 2014), computed tomography (CT) (Lenhard et al., 2009, 2010) and magnetic resonance (Huerta-Enochian et al., 2006; Korhonen et al., 2014; Spörri et al., 2002). CT has been described as the study with the most accurate and reliable picture for high quality pelvimetry (Herrmann et al., 1990; Lenhard et al., 2009, 2010). In most patients it indicated that a caesarean section for cephalopelvic disproportion, it is not based with a pelvimetry based on an imaging study (Santin, 2011).

The morphometric characteristics of the pelvic cavity are important to be described, so the obstetrician can identify and diagnose cephalopelvic disproportion of a narrow pelvis and correctly indicate a cesarean (Santin). The variations in the pelvic parameters of Mexican women have not been reported in the literature, so it is important to compare these with other populations as well as associate any differences regarding age.

The aim of our study was to determine normal values for the anatomic conjugate diameter (ACD), the obstetric conjugate diameter (OCD), the conjugate diameter diagonal (DCD) and the interspinous distance (ISD) using reformatted CT in a Mexican population and determine whether there are significant differences in these parameters regarding age groups.

\section{MATERIAL AND METHOD}

An anatomical, retrospective, observational, transversal, descriptive and comparative study was conducted in collaboration between the Department of Human Anatomy, Faculty of Medicine of the Universidad Autónoma of Nuevo León (U.A.N.L.) and the Department of Radiology and Imaging, University Hospital "Dr. José E. González" of the U.A.N.L.
A sample size (with prior calculation) of 290 abdominopelvic CT (simple or contrasted) of Mexican women with an age range between 18 and 50 years (mean $37.50 \pm 8.46)$ were analyzed. The studies were conducted between January and June 2014. Any CT from patients with structural lesion of the pelvis and its components such as trauma, primary or secondary neoplasms, infections and/or malformations, as well as patients with a diagnosis of pregnancy, were excluded. The CT scans were obtained from the Department of Radiology and Imaging database from patients who needed the image study for other purposes. No patient was radiated for the purposes of this study.

The morphometries of the pelvises were performed in the 3D integration work station (Centricity RIS-i 4.2 Plus [General Electric, Milwaukee, WI]) using reconstructions and were stored in an independent workstation. The equipment used to obtain the images was a General Electric Light Speed VCT 64-slice CT (General Electric, Milwaukee, WI) from the Department of Radiology and Imaging; this CT model is able to continuously scan with a thickness of $2.5 \mathrm{~mm}$. To better visualize the images a multiplanar reformatting program was used, Volume Rendering (software number: 12HW 14.6_SP1-1-1V40_H_H64_G_GTL), to subsequently make a reconstruction of the bony with focus primarily from the T12/L1 level to the neck of the femur, establishing a plane thickness of $0.625 \mathrm{~mm}$ using the algorithm "Bone Plus". The reconstructed images were then transmitted to the workstation "Advantage Workstation AW 4.4" (General Electric, Milwaukee, WI) with a linear precision of 0.01 $\mathrm{mm}$. Calibration of the workstation was predetermined by the manufacturer.

The reconstruction of the CT did not intervene in any way with the normal protocols of realization, storage and delivery of the study results to the patient or physician requesting the scan. The CT scans were evaluated by two radiologists for compliance with the exclusion criteria. The age of the patients was obtained from the physician's order for the CT. Access to patient's records was not necessary.

The CT scans were divided by age groups with the following ranges: $18-29$ years $(n=60), 30-39$ years $(n=$ $90)$ and age $>40(n=140)$, resulting in three study groups (Table I).

For each TC, the following morphometry evaluations were performed:

1. Anatomical conjugate diameter (ACD). Distance between the center of the sacral promontory and the upper border of the pubic symphysis (Fig. 1a). 


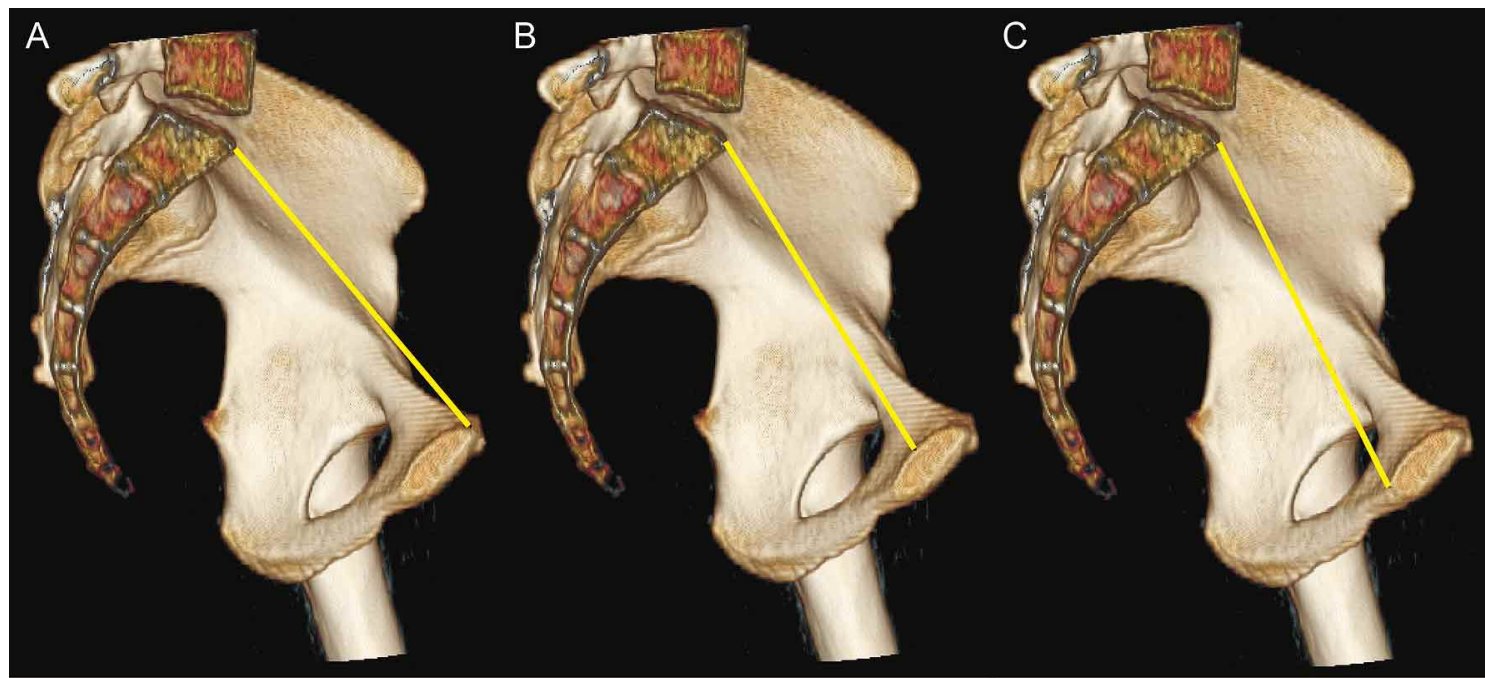

Fig. 1. Images of the pelvis by three-dimensional reconstruction of a CT scan where the measurement technique anatomic conjugate diameter (a), obstetric conjugate diameter (b) and conjugate diameter diagonal (c) is observed.

Table I. Distribution of patients involved in the study according to age ranges.

\begin{tabular}{lc}
\hline Group Age (years) & Number of patients (n) \\
\hline $18-29$ & 60 \\
$30-39$ & 90 \\
$\geq 40$ & 140 \\
Total & 290 \\
\hline
\end{tabular}

2. Obstetric conjugate diameter (OCD). Distance between the center of the sacral promontory and the posterior border of the symphysis pubis (Fig 1b).

3. Conjugate diameter diagonal (DCD). Distance between the center of the sacral promontory and the lower border of the symphysis pubis (Fig. 1c).

4. Interspinous distance (ISD). Distance extending between the medial edge of an ischial spine and the medial border of the contralateral ischial spine (Fig. 2).

The ISD was measured using a posterior plane of the $3 \mathrm{D}$ pelvis; the ACD, OCD and DCD were measured in a sagittal section of the $3 \mathrm{D}$ pelvis. All measurements are reported in centimeters and were stored in a database for subsequent statistical analysis.

Statistical analysis. Statistical analysis was obtained using the computer program SPSS version 21.0 for Windows XP. The sample size was determined with a hypothesis test and difference of two means or with one mean as reference value. The $\mathrm{z} \partial$ value was set at 1.96 (95\% two-tailed confidence interval), and $z ß$ value at 0.84 (power of $80 \%$ ) obtaining a sample of 290 CT scans from the calculations.
The mean and standard deviation for each measurement is determined by groups. Two-tailed student $\mathrm{t}$ Test was used to determine the significance of differences between age groups $(\mathrm{p}<0.05)$. All results are plotted and included in tables.

The ability to replicate measurements is essential for any morphological study, reason why intra- and interobserver error test were made. Each scan was measured a second time, two weeks later by the first author. The differences between the two sets of measurements were used in order to calculate a percentage of error (intraobserver variability) using a Student's pairwise t test for estimating the significance of these results. Finally, in order to assess

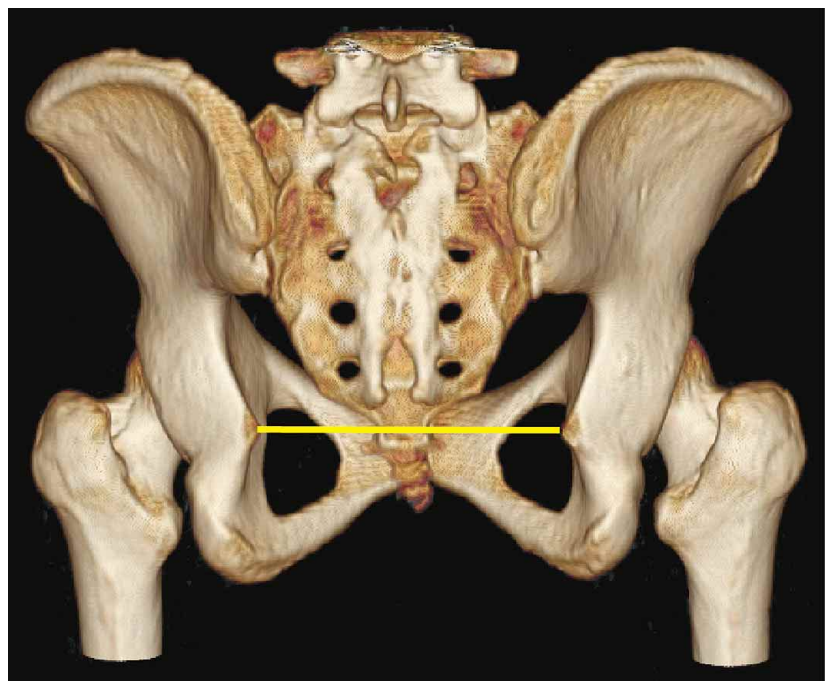

Fig. 2. Images of the pelvis by three-dimensional reconstruction of a CT scan where the measurement technique is observed the interspinous diameter. 
VÁZQUEZ-BARRAGÁN, M. A; GARZA-BÁEZ, A.; MORALES-AVALOS, R.; MARTÍNEZ-GONZÁLEZ, B.; JACOBO-BACA, G.; PINALES-RAZO, R.; QUIROGA-GARZA, A.; DE LA FUENTE-VILLARREAL, D.; ELIZONDO-RIOJAS, G.; ELIZONDO-OMAÑA, R. E. \& GUZMÁN-LÓPEZ, S. Pelvimetry by reformatted Computed Tomography in 290 female pelvis. Morphometric variations regarding age. Int. J. Morphol., 34(1):298-304, 2016.

the interobserver error, a randomized sample of 50 scans was selected and re-measured 2 weeks later by the same person as the first time. The results were compared in a database with Student's pairwise t test.

Ethical considerations. This study was approved by the Ethics and Research Committees of the Faculty of Medicine of the U.A.N.L. with the registration code "AH15-002". There were no financial or commercial gains in the completion of this study. The authors declare no conflict of interest.

\section{RESULTS}

In this study, the mean length for the ACD, OCD, DCD and ISD for Mexican women was calculated using 290 CT scans.

The overall mean of each diameter obtained from the 290 samples is shown in Table II. The mean of each diameter divided by age groups is shown in Table III. The 18-29 years of age group presented the widest diameters in all 4 parameters, with the 40-49 age group with the narrowest diameters in each of the studied parameters.

Table II. Overall morphometric results of the different pelvic diameters in women. A sample of 290 CT scans.

\begin{tabular}{lc}
\hline Diameter & Mean \pm SD $(\mathbf{c m})$ \\
\hline ACD & $11.65 \pm 0.99$ \\
OCD & $11.73 \pm 0.98$ \\
DCD & $12.49 \pm 0.98$ \\
ISD & $10.41 \pm 0.78$ \\
\hline
\end{tabular}

$\mathrm{ACD}=$ Anatomic conjugate diameter. $\mathrm{OCD}=$ Obstetric conjugate diameter. $\mathrm{DCD}=$ Conjugate diameter Diagonal. $\mathrm{ISD}=$ Interspinous diameter.

Table III. Morphometric results of the pelvic diameters classified by age group.

\begin{tabular}{lcc}
\hline Parameter & Group Age (years) & Mean \pm SD $(\mathbf{c m})$ \\
\hline ACD & $18-29$ & $11.95 \pm 1.04$ \\
& $30-39$ & $11.78 \pm 0.99$ \\
& $\geq 40$ & $11.43 \pm 0.94$ \\
OCD & $18-29$ & $12.07 \pm 1.02$ \\
& $30-39$ & $11.86 \pm 0.89$ \\
& $\geq 40$ & $11.51 \pm 0.96$ \\
DCD & $18-29$ & $12.78 \pm 1.07$ \\
& $30-39$ & $12.64 \pm 0.90$ \\
& $\geq 40$ & $12.26 \pm 0.96$ \\
ISD & $18-29$ & $10.56 \pm 0.80$ \\
& $30-39$ & $10.55 \pm 0.78$ \\
& $\geq 40$ & $10.29 \pm 0.80$ \\
\hline
\end{tabular}

$\mathrm{ACD}=$ Anatomic conjugate diameter. $\mathrm{OCD}=$ Obstetric conjugate diameter. $\mathrm{DCD}=$ Conjugate diameter Diagonal. $\mathrm{ISD}=$ Interspinous diameter.
The significance of differences $(\mathrm{p}=<0.05)$ between each age group for each of the evaluated parameter is shown in Table IV. Significant differences was established between the 18-29 group against the $\geq 40$ group, as well as between the 30-39 group against the $\geq 40$ group, for all parameters.

Table IV. Statistical significant difference in the comparison between the mean results of each diameter between the different age groups.

\begin{tabular}{lcc}
\hline Parameter & Comparison Group & $\boldsymbol{P}$ \\
\hline ACD & $18-29$ vs $30-39$ & 0.30 \\
& $18-29$ vs 40 & $0.001^{*}$ \\
OCD & $30-39$ vs $\geq 40$ & $0.007^{*}$ \\
& $18-29$ vs $30-39$ & 0.19 \\
$18-29$ vs $\geq 40$ & $<0.001^{*}$ \\
DCD & $30-39$ vs $\geq 40$ & $0.005^{*}$ \\
& $18-29$ vs $30-39$ & 0.38 \\
& $18-29$ vs $\geq 40$ & $0.001^{*}$ \\
ISD & $30-39$ vs $\geq 40$ & $0.003^{*}$ \\
& $18-29$ vs $30-39$ & 0.48 \\
& $18-29$ vs $\geq 40$ & $0.030^{*}$ \\
& $30-39$ vs $\geq 40$ & $0.016^{*}$ \\
\hline
\end{tabular}

$\mathrm{ACD}=$ Anatomic conjugate diameter. $\mathrm{OCD}=$ Obstetric conjugate diameter. $\mathrm{DCD}=$ Conjugate diameter Diagonal. $\mathrm{ISD}=$ Interspinous diameter. * Statistically significant.

\section{DISCUSSION}

There are few studies in the literature that analyze normal pelvic diameters in the general population (Lenhard et al., 2010), as most of these are determined in pregnant women during labor (Daghighi et al.; Harper et al.; HuertaEnochian et al.; Korhonen et al., 2010; Lenhard et al., 2009; Spörri et al., 1997, 2002). More importantly, no study has established a difference in these parameters regarding age. Our study identified that there are significant differences in all these parameters regarding age.

We determined the normal values for the pelvic parameters ACD, OCD, DCD and ISD, using CT because they are the most important for diagnosing cephalopelvic disproportion. DCD and ISD are usually the ones subjectively examined by finger palpation during labor.

The OCD and the ISD are the most studied pelvic parameters in the literature. As reported in other populations, the OCD varies between 10.7 and $12.5 \mathrm{~cm}$ (Daghighi et al.; Huerta-Enochian et al.; Lenhard et al., 2009, 2010; Spörri et al., 1997, 2002) and ISD varies between $9.6 \mathrm{~cm}$ and 10.8 
VÁZqUEZ-BARRAGÁN, M. A; GARZA-BÁEZ, A.; MORALES-AVALOS, R.; MARTÍNEZ-GONZÁLEZ, B.; JACOBO-BACA, G.; PINALES-RAZO, R.; QUIROGA-GARZA, A.; DE LA FUENTE-VILLARREAL, D.; ELIZONDO-RIOJAS, G.; ELIZONDO-OMAÑA, R. E. \& GUZMÁN-LÓPEZ, S. Pelvimetry by reformatted Computed Tomography in 290 female pelvis. Morphometric variations regarding age. Int. J. Morphol., 34(1):298-304, 2016.

cm (Harper et al.; Huerta-Enochian et al.; Lenhard et al., 2009, 2010; Spörri et al., 1997, 2002). The results obtained in Iranian, American, German and Swiss populations coincide with ours (Table V). Korhonen et al. (2010), studied the ACD in 100 Finnish women in their third trimester of pregnancy using MRI and found values between $11.8 \mathrm{~cm}$ and $12 \mathrm{~cm}$, which are very similar to those of our study results.

In the literature there are no data of variations in these diameters according to age. Our study showed that pelvic diameters narrow with increasing age; women in the group $\geq 40$ years, presented significantly smaller diameters than other age groups (Table III). We recognize that a limitation of this study is that the medical history of each patient involved is unknown. These differences may be related to physiological and endocrine changes, nutritional factors, the amount and intensity of physical activity undertaken by individuals at different stages of life and bone remodelers (Morales-Avalos et al., 2014).

It is very important to determine the morphometric parameters of the pelvis in our population due to the excess in wrongly indicated cesarean. Knowing these parameters can aid in diagnosing cephalopelvic disproportion and correctly indicate the best type of birth during the different stages of life.

We determined the normal values for the pelvic parameters: ACD, OCD, DCD and ISD using CT, and found that the mean for each of the diameters is higher than that reported in the current literature is cataloged as narrow pelvis. We also demonstrated that younger women are more likely to have wider pelvic diameters, which may narrow with increasing age, especially after the age of 40 .

Table V. Comparison of results obtained from studies of different populations in morphometric pelvic parameters.

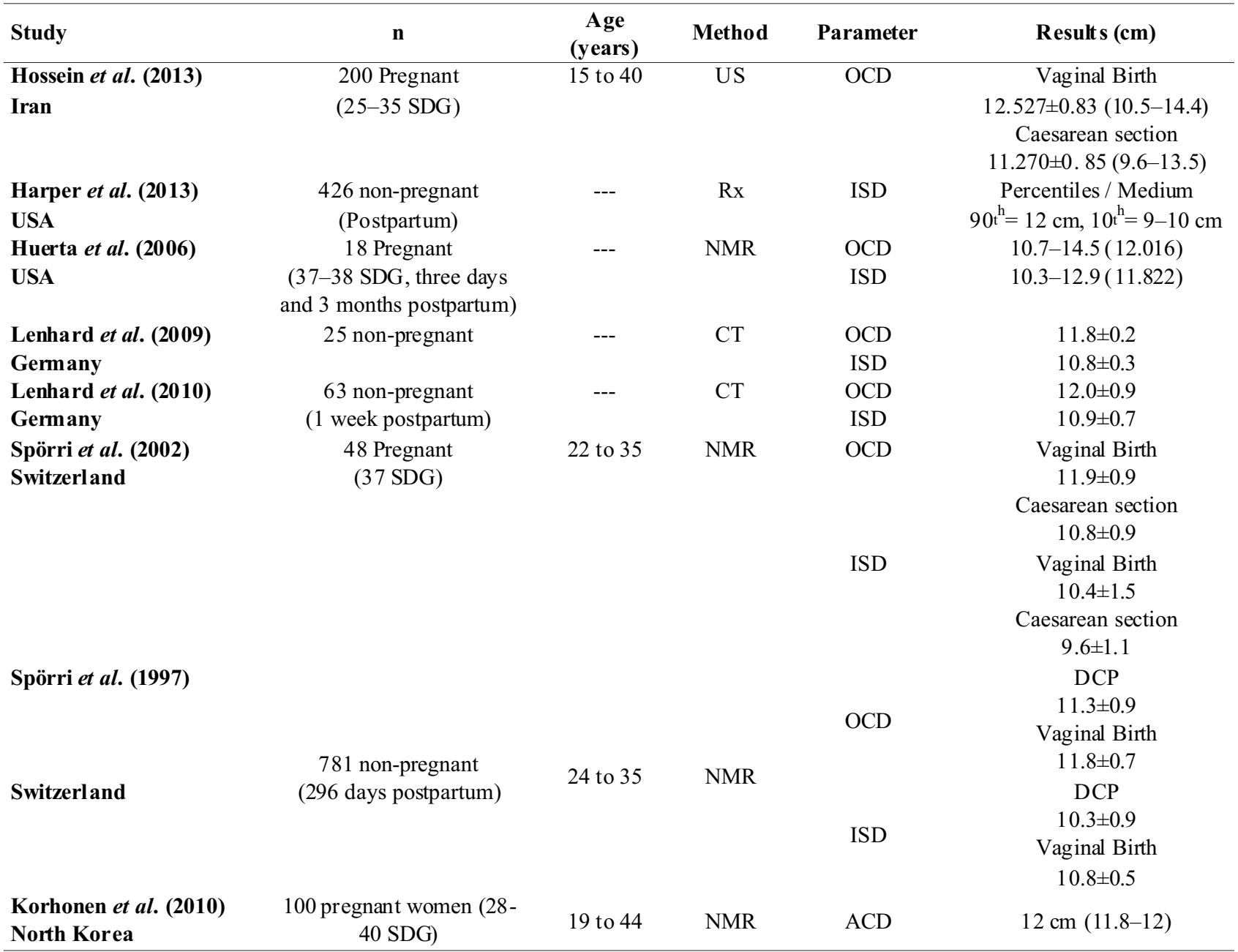

$\mathrm{ACD}=$ Anatomic conjugate diameter. $\mathrm{OCD}=$ Obstetric conjugate diameter. $\mathrm{DCD}=$ Diagonal conjugate diameter. $\mathrm{ISD}=$ Interspinous distance. US= Ultrasound. $\mathrm{NMR}=$ Nuclear magnetic resonance. $\mathrm{Rx}=$ Plain radiographs. $\mathrm{CT}=$ Computed tomography . 
VÁZqUEZ-BARRAGÁN, M. A; GARZA-BÁEZ, A.; MORALES-AVALOS, R.; MARTÍNEZ-GONZÁlEZ, B.; JACOBO-BACA, G.; PINALES-RAZO, R.; QUIROGA-GARZA, A.; DE LA FUENTE-VILLARREAL, D.; ELIZONDO-RIOJAS, G.; ELIZONDO-OMAÑA, R. E. \& GUZMÁN-LÓPEZ, S. Pelvimetry by reformatted Computed Tomography in 290 female pelvis. Morphometric variations regarding age. Int. J. Morphol., 34(1):298-304, 2016.

VÁZQUEZ-BARRAGÁN, M.A; GARZA-BÁEZ,A.; MORALES-AVALOS, R.; MARTÍNEZ-GONZÁLEZ, B.; JACOBO-BACA, G.; PINALES-RAZO, R.; QUIROGA-GARZA,A.; DE LA FUENTE-VILLARREAL, D.; ELIZONDO-RIOJAS, G.; ELIZONDOOMAÑA, R. E. \& GUZMÁN-LÓPEZ, S. Pelvimetría mediante Tomografía Computadorizada reformada en 290 pelvis femeninas. Variaciones morfométricas de acuerdo a la edad. Int. J. Morphol., 34(1):291-297, 2016.

RESUMEN: El Gobierno mexicano aprobó una nueva reforma del artículo 11 de la Ley General del 2014, relativa al acceso de las mujeres a una Vida Libre de Violencia, que establece que una cesárea no se puede realizar si un parto vaginal es viable. Los partos por cesárea son indicados excesivamente en el norte de Mexico, con el diagnóstico de desproporción céfalo-pélvica debido a una estrechez de la pelvis. Actualmente, no existe una morfometría estandarizada de la pelvis femenina en una población mexicana para establecer parámetros de diagnóstico adecuado. Nuestro estudio mide los diámetros pélvicos del canal de parto mediante tomografía compudotarizada (TC) abdomino-pélvica. Se usaron 290 TC de mujeres mexicanas entre 18 y 50 años, los que fueron reformateados en 3D para medir morfológicamente los diámetros pélvicos de relevancia clínica. Las mediciones fueron realizadas por dos especialistas en diagnóstico por imagen. La Media y DE de los diámetros medidos fueron: diámetro anatómico conjugado (DAC) 11,65 $\pm 0,99$ cm, diámetro obstétrico conjugado (DOC) $11,73 \pm 0,98 \mathrm{~cm}$, diámetro diagonal conjugado (DDC) $12,49 \pm 0,98 \mathrm{~cm}$ y distancia interespinosa (DIE) $10,41 \pm 0,78 \mathrm{~cm}$. Se encontraron diferencias significativas en las Medias de los cuatro diámetros entre los grupos de 20-29 años de edad frente a las >40 años, así como entre los grupos de 30-39 años frente a los >40 años. Nuestro estudio muestra que a medida que las mujeres mexicanas avanzan en edad, los diámetros pélvicos medios son más estrechos.

PALABRAS CLAVE: Pelvimetría ; Cesárea; Desproporción céfalo-pélvica; Tomografía compudotarizada reformateada; Morfometría; México.

\section{REFERENCES}

Alijahan, R.; Kordi, M.; Poorjavad, M. \& Ebrahimzadeh, S. Diagnostic accuracy of maternal anthropometric measurements as predictors for dystocia in nulliparous women. Iran. J. Nurs. Midwifery Res., 19(1):11-8, 2014.

Campero, L.; Hernández, B.; Leyva, A.; Estrada, F.; Osborne, J. \& Morales, S. Trends in caesarean sections associated with non-clinical factors in a Birthing Educational Center in Mexico City. Salud Publica Mex., 49(2):118-25, 2007.

Cárdenas, R. Cesarean-associated complications: the importance of a scarcely justified use. Gac. Med. Mex., 138(4):357-66, 2002.

Cunningham, F. G.; Whitridge Williams, J.; Gant, N. F.; Leveno, K. J.; Gilstrap, L. C.; Hauth, J. C. \& Wenstrom, K. D. Williams Obstetrics. 21 ${ }^{\text {th }}$ ed. New York, McGraw-Hill, 2001.

Daghighi, M. H.; Poureisa, M. \& Ranjkesh, M. Association between obstetric conjugate diameter measured by transabdominal ultrasonography during pregnancy and the type of delivery. Iran. J. Radiol., 10(3):185-7, 2013.

Gutiérrez, J. P.; Rivera-Dommarco, J.; Shamah-Levy, T.; Villalpando-Hernández, S.; Franco, A.; Cuevas-Nasu, L.; Romero-Martínez, M. \& Hernández-Ávila, M. Encuesta Nacional de Salud y Nutrición 2012. Resultados Nacionales. Cuernavaca, Instituto Nacional de Salud Pública, 2012.

Harper, L. M.; Odibo, A. O.; Stamilio, D. M. \& Macones, G. A. Radiographic measures of the mid pelvis to predict cesarean delivery. Am. J. Obstet. Gynecol., 208(6):460. e1-6, 2013.

Herrmann, K.; Ketscher, K. D.; Siering, U.; Retzke, U. \& Schmidt,
M. Pelvimetry using computerized tomography. I. Theoretical and methodical fundamentals. Zentralbl. Gynakol., 112(19):1209-15, 1990.

Huerta-Enochian, G. S.; Katz, V. L.; Fox, L. K.; Hamlin, J. A. \& Kollath, J. P. Magnetic resonance-based serial pelvimetry: do maternal pelvic dimensions change during pregnancy? Am. J. Obstet. Gynecol., 194(6):1689-94, 2006.

Korhonen, U.; Solja, R.; Laitinen, J.; Heinonen, S. \& Taipale, P. MR pelvimetry measurements, analysis of inter- and intraobserver variation. Eur. J. Radiol., 75(2):e56-61, 2010.

Korhonen, U.; Taipale, P. \& Heinonen, S. The diagnostic accuracy of pelvic measurements: threshold values and fetal size. Arch. Gynecol. Obstet., 290(4):643-8, 2014.

Lenhard, M.; Johnson, T.; Weckbach, S.; Nikolaou, K.; Friese, K. \& Hasbargen, U. Three-dimensional pelvimetry by computed tomography. Radiol. Med., 114(5):827-34, 2009.

Lenhard, M. S.; Johnson, T. R.; Weckbach, S.; Nikolaou, K.; Friese, K. \& Hasbargen, U. Pelvimetry revisited: analyzing cephalopelvic disproportion. Eur. J. Radiol., 74(3):e107-11, 2010.

Morales-Avalos, R.; Leyva-Villegas, J.; Sánchez-Mejorada, G.; Cárdenas-Serna, M.; Vílchez-Cavazos, F.; Martínez-Ponce De León, A.; Elizondo-Riojas, G.; Martínez-García, J.; De la Garza-Castro, O.; Elizondo-Omaña, R. \& Guzmán-López, S. Age- and gender-related variations in morphometric characteristics of thoracic spine pedicle: A study of 4,800 pedicles. Clin. Anat., 27(3):441-50, 2014. 
VÁZqUEZ-BARRAGÁN, M. A; GARZA-BÁEZ, A.; MORALES-AVALOS, R.; MARTÍNEZ-GONZÁLEZ, B.; JACOBO-BACA, G.; PINALES-RAZO, R.; QUIROGA-GARZA, A.; DE LA FUENTE-VILLARREAL, D.; ELIZONDO-RIOJAS, G.; ELIZONDO-OMAÑA, R. E. \& GUZMÁN-LÓPEZ, S. Pelvimetry by reformatted Computed Tomography in 290 female pelvis. Morphometric variations regarding age. Int. J. Morphol., 34(1):298-304, 2016.

Penn, Z. \& Ghaem-Maghami, S. Indications for caesarean section. Best Pract. Res. Clin. Obstet. Gynaecol., 15(1):1-15, 2001.

Puentes-Rosas, E.; Gómez-Dantés, O. \& Garrido-Latorre, F. Caesarean sections in Mexico: tendencies, levels and associated factors. Salud Publica Mex., 46(1):16-22, 2004.

Rozenholc, A. T.; Ako, S. N.; Leke, R. J. \& Boulvain, M. The diagnostic accuracy of external pelvimetry and maternal height to predict dystocia in nulliparous women: a study in Cameroon. B.J.O.G. 114(5):630-5, 2007.

Santín, G. Caesarean section for cephalo-pelvic disproportion performed without evidence. Does the radiological pelvimetry has a place in obstetrics today? Ginecol. Obstet. Mex., 79(6):368-72, 2011

Spörri, S.; Hänggi, W.; Braghetti, A.; Vock, P. \& Schneider, H. Pelvimetry by magnetic resonance imaging as a diagnostic tool to evaluate dystocia. Obstet. Gynecol., 89(6):902-8, 1997.

Spörri, S.; Thoeny, H. C.; Raio, L.; Lachat, R.; Vock, P. \& Schneider, H. MR imaging pelvimetry: a useful adjunct in the treatment of women at risk for dystocia? AJR Am. J. Roentgenol., 179(1):137-44, 2002.

Tita, A. T. When is primary cesarean appropriate: maternal and obstetrical indications. Semin. Perinatol., 36(5):324-7, 2012.

Villar, J.; Carroli, G.; Zavaleta, N.; Donner, A.; Wojdyla, D.; Faundes, A.; Velazco, A.; Bataglia, V.; Langer, A.; Narváez, A.; Valladares, E.; Shah, A.; Campodónico, L.; Romero, M.; Reynoso, S.; de Pádua, K. S.; Giordano, D.; Kublickas, M.; Acosta, A. \& World Health Organization 2005 Global Survey on Maternal and Perinatal Health Research Group. Maternal and neonatal individual risks and benefits associated with caesarean delivery: multicentre prospective study. $B M J$, 335(7628):1025, 2007.
Correspondence to:

Dr. Miguel Ángel Vázquez-Barragán

Departamento de Anatomía Humana

Facultad de Medicina

Universidad Autónoma de Nuevo León

Ave. Madero, C.P.64460.

Monterrey, Nuevo León

MÉXICO

Tel: (+52) (81)83294171

Email: mavb.00@gmail.com

Received: 30-10-2015

Accepted: 24-12-2015 